\title{
Biosystematic studies on Dactylis L. 2. Original research. 2.1. Morphological differentiation and occurrence of representatives of the genus Dactylis in Poland. 2.1.2. Distribution of Dactylis glomerata subsp. slovenica (Dom.) Dom. in Poland and adjacent regions
}

MARTA MIZIANTY

W. Szafer Institute of Botany, Polish Academy of Sciences, Lubicz 46, 31-512 Kraków, Poland

(Received: November 11, 1987. Revision accepted: May 5, 1988)

\begin{abstract}
This paper presents the results of analysis of herbarium materials from Poland, Czechoslovakia, the USSR, East Germany and belonging to the author, as well as data from literature dealing with the distribution of D. glomerata subsp. slovenica (Dom.) Dom. in Poland and adjacent regions. It was found that D.g. subsp. slovenica occurs in 33 localities ( 30 herbarium and 3 literature) in Poland. The distribution of this subspecies is presented for the first time for Poland. All the localities of D.g. subsp. slovenica were found in the mountainous parts of Poland (Sudety Mts. and the Carpathians). In territories adjacent to Poland, D.g. subsp. slovenica was found in the Czech Massif and in many stands in the Western and Eastern Carpathians and also in Roztocze Upland.
\end{abstract}

Key words: Dactylis glomerata subsp. slovenica (Dom.) Dom., distribution, Poland, regions adjacent to Poland

\section{INTRODUCTION}

Dactylis slovenica was first discovered by Domin (1923) on the outskirts of a beech wood in the Strażowskie Mts. in the district of Zljechov in Western Slovakia (Czechoslovakia). Domin (1.c.) initially gave only a general description of the morphology and habitats of this new species in Czech language. $\mathrm{He}$ gave a Latin diagnosis for $D$. slovenica in 1929 , mentioning $D$. slovenica from the Belanské Tatry Mts. (Domin 1929). In the latter paper Domin (l.c.) also made some general remarks on the distribution and habitat of D. slovenica. Earlier, in 1928, Domin and Podpera degraded D. slovenica to the rank of a subspecies belonging to $D$. glomerata. Finally, in a monograph on the genus 
Dactylis (Domin 1943) D. slovenica is mentioned in the rank of a subspecies of D. glomerata. In this monograph, D.g. subsp. slovenica was treated as of equal rank with D.g. subsp. euglomerata, altaica, himalayensis, hispanica and polygama.

The results of this author's own research on materials in Poland (Mizianty 1988) also suggest that this taxon should be assigned the rank of subspecies and treated as equal to D.g. subsp. glomerata and D.g. subsp. aschersoniana.

D.g. subsp. slovenica, according to Domin (1943), is characterized by its great height (up to $1.5 \mathrm{~m}$ ), straw-green leaves, long $(20-25 \mathrm{~cm})$ and single-sided panicle with markedly far apart branches, elongated-lanceolate glumes and lemmas which are non ciliated, smooth on the surface and nated or ciliated on the rib. This is a plant without stolons. It grows on limestone or dolomite, in mountain or subalpine plant associations, or sometimes descends to uplands.

The present author, on the basis of biometric and experimental research on materials from Poland (Mizianty 1988) has established the specific morphological characters distinguishing this subspecies from two others occurring in Poland, i.e. D.g. subsp. glomerata and D.g. subsp. aschersoniana. These characters include: the height of the plant over $1 \mathrm{~m}$, leaf breadth over $6 \mathrm{~mm}$, panicle longer than $15 \mathrm{~cm}$, stem thickened at the base to a diameter of $5 \mathrm{~mm}$ or more.

According to Domin (1943), D.g. subsp. slovenica is characteristic of the Western Carpathians. On the west of this mountain range it occurs in stands distant from one another (Moravia, Eastern Bohemia), and on the east it reaches the Eastern Carpathians (it occurs in the northern part of the Ukraine).

The author's earlier studies (Mizianty 1988) showed that D.g. subsp. slovenica occurs in Poland. The occurrence of this subspecies has been established in seven stands, of which three (in the Bieszczady Mts.) were reported earlier by Jasiewicz (1965).

\section{MATERIAL}

The studies now reported were based on a critical analysis of Polish and foreign herbaria.

The following herbaria from Poland were reviewed: KRA, KRAM, KTU, LBL, LOD, POZ, WA, WRSL, TRN, WSRP, BIL ${ }^{x}, \mathrm{KTCB}^{\mathrm{x}}, \mathrm{OLSM}^{\mathrm{x}}, \mathrm{SLTC}^{\mathrm{x}}$, $\mathrm{SZCZ}^{\mathrm{x}}, \mathrm{UGDA}^{\mathrm{x}}, \mathrm{hb} . \mathrm{Mąd}^{\mathrm{x}}$, hb. Mir ${ }^{\mathrm{x}}$ (2500 sheets in all). These herbaria have the most numerous collections in Poland; the flora of more or less all the regions of the country is represented in them.

Foreign herbaria were also analysed: from Czechoslovakia: PR, PRC, SAV, SLO, (1060 sheets in all); from the USSR: LWD, LW, KW, KWHA (600 sheets in all); from East Germany: DR, HAL, JE, LZ (800 sheets in all). 
To these, the author's own Polish and foreign collections (MM) were also added (1500 sheets in all).

The abbreviations of the names of the herbaria (except MM) are given according to Index Herbariorum (1981) and Mirek (manuscript). The later are marked " $x$ ".

In the most of the herbaria studied, D.g. subsp. slovenica was not distinguished earlier and was described as D. glomerata L.

As a supplement to the herbarium studies, data from Domin $(1923,1943)$ and Hendrych (1986) on the occurrence of D.g. subsp. slovenica in Czechoslovakia, from Domin (1943) and Malinovsky (1962) in the Ukrainian Carpathians, and Jasiewicz (1965) in the Polish Bieszczady Mts. were included.

\section{RESULTS}

The map (Fig. 1) together with the list of stands show the distribution of D.g. subsp. slovenica in Poland and adjacent territories.

From revision of the herbarium material in Poland and the author's own studies it follows that D.g. subsp. slovenica occurs in Poland. The occurrence of this plant in 30 stands has been established. So far this taxon has not been mentioned in the many floristic and geobotanical elaboration of different regions of Poland. As already mentioned, only Ja siewicz (1965) noticed D.g. subsp. slovenica in three stands in the Bieszczady Mts.

The finding of stands of D.g. subsp. slovenica in Poland gives evidence of the mountain character of this subspecies. All are found solely in the south, i.e. in the mountainous part of Poland. According to the physicogeographical division of Poland (Kondracki 1978), the area in which this subspecies appears lies in two mountain provinces. They are the Czech Massif (subprovince: Sudety Mts. with Przedgórze, stand 1), and the Carpathians (subprovince: Outer Western Carpathians, stands 2-10; subprovince: Central Western Carpathians, stands 11-20; and subprovince: Eastern Beskids or Outer Eastern Carpathians, stands 21-30). The names of the macro-and meso-regions entering into the composition of the particular subprovinces in Poland are given in the list of stands.

The occurrence of D.g. subsp. slovenica (a mountain herb layer plant) in numerous stands below the upper forest limit in the Polish Carpathians may be explained by the well-known phenomenon of the descent of plants from mountain conditions downwards along streams and rivers. The very damp ground favours this, and as is known, tall herbaceous plants, by their nature, appear in just such places. Calciphilous species especially have favourable conditions for translocation, and subsp. slovenica is one of these. A favourable element is the property of river gravels and sands, which to a certain degree 


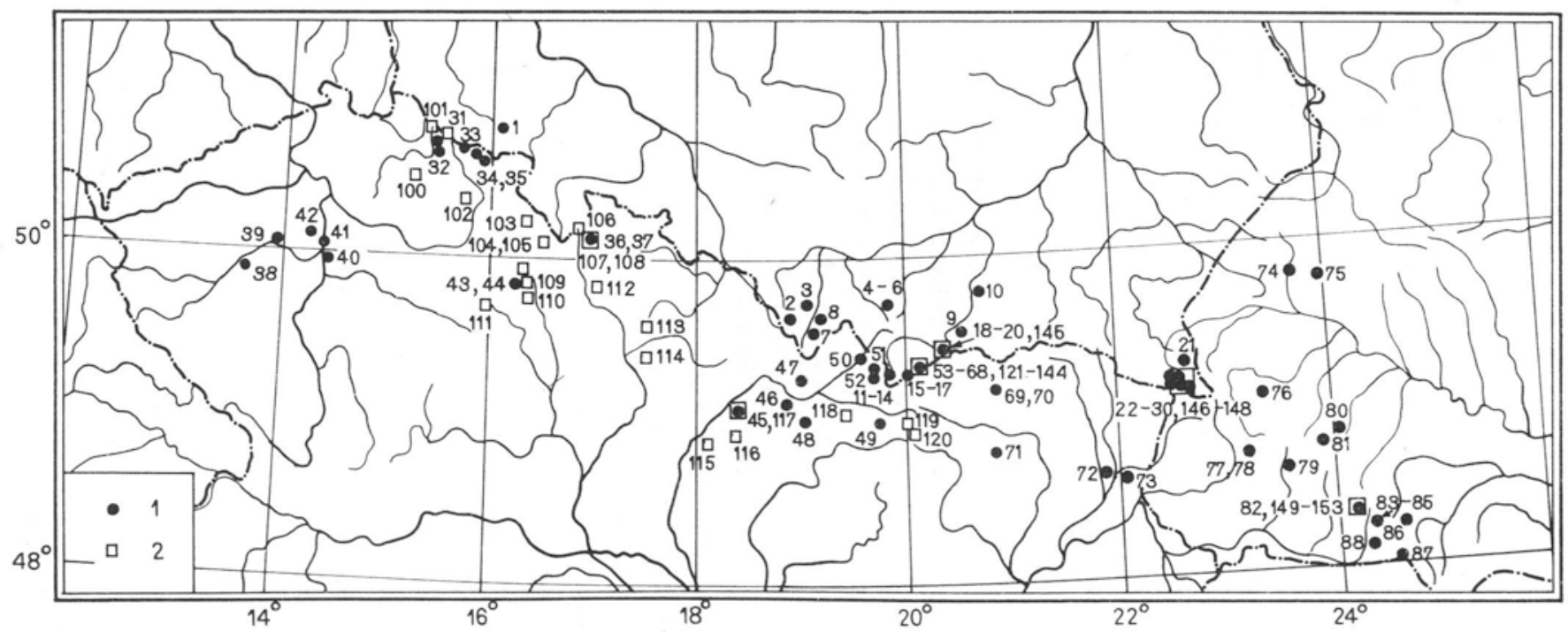

Fig. 1. Distribution of Dactylis glomerata subsp. slovenica in Poland and adjacent regions. 1 - herbarium material, 2 - literature data 
replace the lime ion, and this substrate with regard to other chemical and physical properties closely approaches a limestone substrate (Walas 1938, Lazar 1966).

The stands of D.g. subsp. slovenica found by the author in the Polish Carpathians clearly indicate the calciphilous character of this plant. This subspecies was collected for instance from three stands in the Pieniny Mts. This region is typical for a large number of calciphilous plants. In general the Carpathian flora is of a character intermediate between the "granite" and "limestone" flora of the Tatras. This is caused by the great mosaic of rocks entering into the cmposition of flysch, of which the main mass of the Carpathians is composed. This flysch character of the Carpathians, in spite of the frequent scarcity of limestone rocks, presents no impediment to the development of calciphilous species (Białecka 1982.). Both in corries and river valleys various transitional forms of soil are found, and soils rich in calcium carbonate may occur locally (Lazar 1957).

Taking as a basis the detailed geobotanical elaborations of the areas from which D.g. subsp. slovenica comes, knowledge of the geological structure and of soils in the stands of this subspecies may be gained. This analysis clearly indicates the calciphilous character of this plant.

Review of the herbarium materials from regions adjacent to Poland shows a more extensive area of occurrence of this subspecies than has hitherto been given (Domin 1943, Flora Europaea 1980), since besides the Carpathians it appears in many stands also in the second geological unit i.e. in the Czech Massif (Karkonosze Mts., Jesenik Mts., and Czech Basin). The stand of subsp. slovenica further to the west is that in the Czech Massif (about forty km to the west of Prague). The numerous stands in the Eastern Carpathians (Skolievskye Beskidy Mts., Czarnohora Mts., Svidovec Mts., Gorgany Mts.), and others in the Zakarpatskaya District as well as in the Roztocze Upland are stands extending further to the east in this mountain range. From the data in literature (Zapałowicz 1889, Szafran 1933) and from personal information (Professor Malinovsky, Institute of Botany Ukrainian Academy of Sciences, Lwów), it follows that D.g. subsp. slovenica occurs very frequently in the Eastern Carpathians (Svidovec Mts., Czarnohora Mts.).

When analysing the distribution of this subspecies on the basis of the herbarium materials, three stands beyond the Roztocze, the Carpathians and the Czech Massif should be kept in mind. Two of them are in the region of Kiev (USSR), on the Dniepr Upland and Kiev Polesie, and the third in the Dynarskie Mts. (Yugoslavia). On the Dniepr Upland D.g. subsp. slovenica may occur as an introduced plant, since the reserve in which it was found originated on the ground of a park laid out at the end of the eighteenth century by artificial plantation (Lipa and Fedorenko 1969). The stand in Yugoslavia is in accordance with the mountain and calciphilous character of this subspecies. It is found, however, in a completely separate mountain range. It 
may be assumed that the occurrence of D.g. subsp. slovenica is not confined only to the Eastern and Western Carpathians and the Czech Massif and Roztocze and that perhaps this taxon also appears in the Southern Carpathians, and further in the adjacent Dynarskie Mts. This is still an open question and requires studies.

\section{CONCLUSION}

On the basis of the analysis of Polish herbarium materials it may be stated that D.g. subsp. slovenica occurs in Poland in both the Western and Eastern Carpathians and also in the Sudety Mts. It is a calciphilous plant, growing in mountain tall herb layer associations and it also occurs lower, along streams and rivers of the lower subalpine wood and plateau. It is found in alder thickets and thickets on rivers, as well as on the edges of woodland streams. As an introduced plant it may occupy other fertile sites favouring the development of tall herbaceous plants.

In territories adjacent to Poland, D.g. subsp. slovenica has been found to. occur in the Czech Massif (the Sudety Mts., the Czech Basin) and in many stands in the Western and Eastern Carpathians and also in the Roztocze Upland.

The finding of three stands besides the Carpathians, the Czech Massif and Roztocze Upland (Dniepr Upland, Kiev Polesie and Dynarskie Mts.) suggests that the range of occurrence of this taxon may be even wider.

LIST OF HERBARIUM STANDS OF D.G. SUBSP. SLOVENICA (DOM.) DOM.

Explanations: Poland (1-30)*,

Czechoslovakia (31-73),

USSR (74-88 +2 stands not numbered and not marked on the map),

Yugoslavia (1 locality not numbered and not marked on the map).

SUDETY MTS. (CENTRAL SUDETY MTS.)

1. Wałbrzyskie Mts., Chełmiec Mt., meadow not far from a water-supply, 04.07.1962, H. Surmińska, WRSL

* In the list of localities from Poland the physicogeographical distribution according to Kondracki (1978) was used, in brackets corresponding with it geobotanical distribution of Poland according to Szafer and Zarzycki (1977) is given. 
2. Śląski Beskid Mts. (subdiv. Śląsko-Babiogórski), environs of Kubalonka Pass, at the tourist track to the Barania Góra Mt., 05.08.1986, MM

3. Żywiec Basin, (subdiv. Śląsko-Babiogórski), Łodygowice, permanent gravel heap, $380 \mathrm{~m}$ a.s.1., 20.06.1977, G. Czarkowska, KTU

4. Makowski Beskid Mts. (subdịv. Śląsko-Babiogórski), Jordanów, above railway station in brushes on the bank of the Skawa River, vicinity of a bridge over a side-track, $454 \mathrm{~m}$ a.s.1., 17.06.1966, M. J. Guzikowie, KRAM

5. Makowski Beskid Mts. (subdiv. Śląsko-Babiogórski), Jordanów, on the border of brushes on the Skawa River vis-à-vis the hamlet Rapaczówka, $450 \mathrm{~m}$ a.s.1., 17.06.1966, M. J. Guzikowie, KRAM

6. Makowski Beskid Mts. (subdiv. Śląsko-Babiogórski), Jordanów, on the bank of brushes on the Skawa River, between the railway station and bridge, 07.07.1978, MM

7. Żywiecki Beskid Mts. (subdiv. Śląsko-Babiogórski), slopes of Jaworzyna Mt. above Rycerka-Kolonia village, spruce forest with beech brushwood, $800 \mathrm{~m}$ a.s.1., 12.06.1971, hb. Mir*

8. Żywiecki Beskid Mts. (subdiv. Śląsko-Babiogórski), Soblówka, H. Piękoś, K. Polonek, WA, KRAM

9. Sądecki Beskid Mts. (subdiv. Sądecki), Roztoka Wielka near Rytro, burdock brushes on the stream, 14.08.1979, MM

\section{OUTER WESTERN CARPATHIANS - ŚRODKOWOBESKIDZKIE PLATEAU} (WESTERN CARPATHIANS - BESKIDY MTS.)

10. Rożnów Plateau, (subdiv. Flysch Plateau), vicinity of Gródek at Dunajec River, between Koszarka and Lipie, in brushes on the border of forest, 26.06.1977, MM

\section{CENTRAL WESTERN CARPATHIANS - TATRA RANGE (TATRA MTS.)}

11. Western Tatra Mts. (subdiv. Western Tatra), Kościelisko, lower (mixed) mountain forest zone, 03.08.1911, A. Żmuda, POZ, WA, KRAM

12. Western Tatra Mts. (subdiv. Western Tatra), Wrótka Pass under Giewont Mt, c. $1600 \mathrm{~m}$ a.s.1., 07.08.1973, hb. Mir*

13. Western Tatra Mts. (subdiv. Western Tatra), Chochołowska Valley, not far from the hospice, 10.08.1985, MM

14. Western Tatra Mts. (subdiv. Western Tatra), Jarząbcza Valley, at the stream, 10.08.1985, MM

15. Eastern Tatra Mts (subdiv. High Tatra), Rusinowa glade, $1210 \mathrm{~m}$ a.s.l., 29.08.1977, hb. Mir* 
16. Eastern Tatra Mts. (subdiv. High Tatra), by the road to the Morskie Oko Lake, c. $1390 \mathrm{~m}$ a.s.1., 08.08.1973, hb. Mir*

17. Eastern Tatra Mts. (subdiv. High Tatra), Pięć Stawów Polskich Valley, refuse dump not far from the hospice, $1665 \mathrm{~m}$ a.s.l., 03.09.1977, hb. Mir*

CENTRAL WESTERN CARPATHIANS - ORAWSKO-PODHALAŃSKIE DEPRESSION (PIENINY MTS.)

18. Pieniny Mts. (subdiv. Central Pieniny), Toporzyska glade, margin of forest, $600 \mathrm{~m}$ a.s.1., 15.07.1987, MM

19. Pieniny Mts. (subdiv. Central Pieniny), Walusiówka glade, $700 \mathrm{~m}$ a.s.l., 15.07.1987, MM

20. Pieniny Mts. (subdiv. Małe Pieniny), Wysoka Skałka Mt, west slope, 980 m a.s.1., 16.07.1987, MM

EASTERN BESKIDY - OUTER EASTERN CARPATHIANS - FOREST BESKIDY (EASTERN CARPATHIANS)

21. Sanocko-Turczańskie Mts. (subdiv. Przemyskie Plateau), on the road Czarna-Lutowiska, between bus stops "Polana Ostre" and "Kamieniołomy", by the road on the border of forest, 08.07.1979, MM

22. Western Bieszczady Mts. (subdiv. Bieszczady), road from Bereżki Górne to Magura Stuposiańska, c. $800 \mathrm{~m}$ a.s.1., 24.06.1973, hb. Mir*

23. Western Bieszczady Mts. (subdiv. Bieszczady), Połonina Caryńska Mt., on the border of forest, $1030 \mathrm{~m}$ a.s.1., 22.08.1956, A. Jasiewicz, K. Zarzycki, KRAM

24. Western Bieszczady Mts. (subdiv. Bieszczady), Połonina Caryńska Mt., 22.06.1973, hb. Mir*

25. Western Bieszczady Mts. (subdiv. Bieszczady), Krutówka in the valley of Muczny Stream, alder grove, $680 \mathrm{~m}$ a.s.1., 07.07.1960, A. Jasiewicz, KRAM

26. Western Bieszczady Mts. (subdiv. Bieszczady), valley of Wołosaty Stream, between Ustrzyki Górne and Bereżki, $620 \mathrm{~m}$ a.s.1., 26.06.1962, A. Jasiewicz, KRAM

27. Western Bieszczady Mts. (subdiv. Bieszczady), Bereżki, burdock brushes by Wołosaty Stream, 08.07.1979, MM

28. Western Bieszczady Mts. (subdiv. Bieszczady), Brzegi Górne, brush by Prowcza Stream, 09.07.1979, MM

29. Western Bieszczady Mts. (subdiv. Bieszczady), "Sine Wiry" on the bank of Wetlina Stream, 10.07.1984, MM

30. Western Bieszczady Mts. (subdiv. Breszczady), $300 \mathrm{~m}$ north of Bereżki burdock brushes by Wołosaty Stream, 08.07.1979, MM

31. Špindlerův Mlyn, Krkonoše Mts., 10.09.1986, M. Mizianty, MM 
32. Bíner near Vrchlabi, Krkonoše Mts., meadow on calcareous soil, 10.09.1986, M. Mizianty, MM

33. Vizov near Albeřice, Rýchorskié Hory, Krkonoše Mts., 11.09.1986, M. Mizianty, MM

34. Horni Albeřice, Krkonoše Mts., brush on the old limestone pit, 11.09.1986, M. Mizianty, MM

35. Horni Albeřice, Krkonoše Mts., on the limestone pit, $800 \mathrm{~m}$ a.s.l., 07.07.1949, J. Sourek, PR

36. Velká Kotlina, Vysoky Jesenik Mts., $1200 \mathrm{~m}$ a.s.l., 27.06.1951, M. Deyl, PR

37. Velká Kotlina, near Praděd Mts., Vysoki Jesenik Mts., 05.07. 1947, M. Deyl, PR

38. Skryje on the Mże River (present name Berounka River), 1943, J. Hofman, PR

39. Valley of Kličava River near Zbečno, 09.07.1947, M. Deyl, J. Trakal, PR

40. Průhonice near Praha, 06.10.1950, M. Deyl, PR

41. Praha "Stromovka", 06.1898, J. Rohlena, JE

42. Roztoky near Praha, in a shady forest, 06.1898, J. Rohlena, JE

43. Sloupnice near Litomyšl, 1910, B. Fleischer, PR

44. Sloupnice near Litomyšl, 12.06.1911, B. Fleischer, JE

45. Strážov Mt. near Zljechov, 06.08.1920, K. Domin, PRC

46. Žilina, Malá Fatra Mts., on the meadow near shelter-home, 01.08.1919, K. Domin, PRC

47. Krivaň, Malá Fatra Mts., on a meadow near the shelter-home, 01.08.1919, K. Domin, PRC

48. Malá Križna, Velka Fatra Mts, c. $1150 \mathrm{~m}$ a.s.l., on a meadow on the outskirts of a beech wood, 30.06.1953, Schidlay, O. Grebeńsca, SAV

49. Ďumbier, Nižne Tatry Mts., 02.08.1967, M. Deyl, J. Sojak, PR

50. Between Huty and Zuberec, Západné Tatry Mts., $830 \mathrm{~m}$ a.s.1., 30.08.1975, Z. Mirek, hb. Mir.*

51. Osobitá, Západné Tatry Mts., c. $1280 \mathrm{~m}$ a.s.l., the border of forest, limestone, 15.07.1965, J. Futak, SAV

52. Roháčska Valley, Západné Tatry Mts., c. 1200-1300 m a.s.l., 13.08.1935, J. Dostal, F.A. Nowak, PRC

53. Červená hlína, Belanské Tatry Mts., c. 1250 m a.s.l., 13.07.1961 J. Futak, SAV

54. Holubyho Valley, Skalné Vráta (Siedmich Prameňov Valley), Belanské Tatry Mts., 01.08.1961, Z. Pouzar, PR

55. Siedmich Prameňov Valley, Belanské Tatry Mts., 09.07.1957, H. Piotrowska, UAM

56. Drabina, Belanské Tatry Mts., 27.08.1937, K. Domin, PRC

57. Čierna voda, Belanské Tatry Mts., 09.08.1937, K. Domin, PRC

58. Rigelský Potok, Belanské Tatry Mts., 23.07.1929, Krajina, K. Domin PRC 
59. Košar, Belanské Tatry Mts., $1600 \mathrm{~m}$ a.s.1., 20.08.1935, K. Domin, PRC

60. Kobyli Vrch, Belanské Tatry Mts., 1120 m a.s.1., 24.07.1937, J. Domin, PRC

61. Skalné Vrata, Belanské Tatry Mts., $1290 \mathrm{~m}$ a.s.l., 06.09.1984, M. Mizianty, MM

62. Siedmich Prameňov Valley. Belanské Tatry Mts., 06.09.1984, M. Mizianty, $\mathrm{MM}$

63. Tristarská Valley, Belanské Tatry Mts., 07.09.1984, M. Mizianty MM

64. Čierna Valley, Belanské Tatry Mts., 07.09.1984, M. Mizianty, MM

65. Rigelský Stream (Monkova Valley), Belanské Tatry Mts., 09.09.1984, M. Mizianty, MM

66. Tatranská Valley, Belanské Tatry Mts., c. $1200 \mathrm{~m}$ a.s.1., 08.10.1954, E. Schidlay, SAV

67. Javorova Valley, Belanské Tatry Mts., c. $1550 \mathrm{~m}$ a.s.1., 23.08.1955, J. Dostal PRC

68. Dlhy Vrch, Belanské Tatry Mts., c. $830 \mathrm{~m}$ a.s.1., 06.07.1933, K. Domin, PRC

69. Lipany near Sabinów, ..., 08.1952, J. Majovský, SLO

70. Lipany near Sabinów, vicinity of Malá Skalka, ..08.1952, J. Majovský, SLO

71. Turnanský Hrad, Kras, 13.05.1950, E. Schidlay, SAV

72. Viničky, 04.06.1959, J. Zaborsky, SLO

73. Bodrog (Sv. Maria), vicinity of old Tica-bed, 02.11.1965, J. Majovský, SLO

74. Janów near Gorodok, Roztocze Upland in oak-pine forest, 1934, J. Mądalski, hb. Mąd*

75. Lesienica near Lwow, Roztocze Upland on the bank of a little stream, 02.06.1934, J. Mądalski, hb. Mąd*

76. Zholovchik, Skolievskye Beskidy Mts., $800 \mathrm{~m}$ a.s.1., 17.07.1938, ..., LWD

77. Volovets, Zakarpatskaya Distr., in brushes, 02.07.1949, K. A. Malinovsky, LWD

78. Temnatik Mt near Volovets, Zakarpatskaya Distr,. slopes of gill with beech wood, 11.07.1949, ... LWD

79. Valley of Roztoka river, Zakarpatskaya Distr,. $900 \mathrm{~m}$ a.s.l., between Sinovirska Polana and Sinovir, 07.07.1933, A. Laska, PR

80. Osmoloda, Gorgany Mts., on meadows, 15.06.1963, Byerko, LWD

81. Lugi, Gorgany Mts., 15.07.1939, Fotyenuk, LWD

82. Svidovec Mts., at the Diana Stream, 800 m a.s.1., 22.07.1926, J. Klásterský, PR

83. Pietros Mt., Czarnohora Mts., c. 1500 m a.s.l., 1930, Kozij, Yermachenko, LWD

84. Pietros Mt., Czarnohora Mts., on the N slope, 1935, J. Mądalski, hb. Mąd* 
85. Czarnohora Mts., by the road to the old clearing, 22.07.1900, Janowski, LWD

86. Vielikij Stefulec Mt., Zakarpatskaya Distr., c. $1235 \mathrm{~m}$ a.s.l., at the stream, 23.07.1935, J. Mądalski, LWD

87. Mala Budyjovska Mt., Zakarpatskaya Distr., c. $1535 \mathrm{~m}$ a.s.l., abrupt slope not covered with plants, 18.07.1935, J. Mądalski, LWD

88. Pietrys Mt., Zakarpatskaya Distr., near Trebusany, 1650-1784 m a.s.l. $\ldots, 08.1933$, M. Deyl, PR

- USSR, Dniepr Upland, reservation "Oleksandrya" c. $100 \mathrm{~km}$ at S-W from Kijev, near Belaya Cerkov, 22.05.1977, G. V. Klashtorna, KWHA

- USSR, Kiev Polesie, Gurovshchina, Kijevskaya Distr., oak wood, 24.06.1978, Antonyuk, KWHA

- Yugoslavia, Dynarskie Mts., Cetinje, Montenegro,....07.1899, E. Sagorski, JE

LIST OF LITERATURE STANDS OF D.G. SUBSP. SLOVENICA (DOM.) DOM.

Explanations: Czechoslovakia (100-145), Domin 1923, 1943, Hendrych 1986, Poland (146-148), Jasiewicz 1965,

USSR (149-153), Domin 1943, Malinovsky 1962.

100. Mnichovo Hradišté, Hendrych 1986

101. Krkonoše Mts., Hendrych 1986

102. Podzvičinsk near Dvor Králove, Domin 1943, Hendrych 1986

103. Between Luzino Udoli and Anenská Huta near Destna, Orlicke Hory Mts., Hendrych 1986

104. Vrchni Orlice near Bartosovice, Orlicke Hory Mts., Hendrych 1986

105. Klášterka near Orlica, Orlicke Hory Mts., Hendrych 1986

106. Krălicki Sněžnik, Hruby Jesenik Mts., Hendrych 1986

107. Velka Kotlina, Hruby Jesenik Mts., Hendrych 1986

108. Zámčisko shelter-home in Divoka Desna River valley, Hruby Jesenik Mts., Hendrych 1986

109. From Kerhatice to Hrádek near Usti et Orlica, Českomoravské Mezihori Mts., Domin 1943, Hendrych 1986

110. Česká Třebova, Ceskomoravské Mezihori Mts., Domin 1943, Hendrych 1986

111. Studnice near Ždár, Ždarské Vrchy Mts., Hendrych 1986

112. Between Sobášov and Mladeč near Litovel, Hendrych 1986

113. Drahotuša near Hranice, Moravia, Hendrych 1986

114. Pálenica Mt near Bystřice, Moravia, Domin 1943, Hendrych 1986 
115. Inovec Mt., $1042 \mathrm{~m}$ a.s.l., Domin 1943

116. Rokoše Mts., 1000 m a.s.l., Domin 1943

117. Strážov Mt. near Zljechov, Domin 1923

118. Salatin, Nižné Tatry Mts., 1300-1500 m a.s.l., Domin 1943

119. Turkavá et Černý Vah river, Nižné Tatry Mts., 1100 m a.s.l., Domin 1943

120. Kralová hola, Nižné Tatry Mts., 1600-1700 m a.s.l., Domin 1943

121-144 BELANSKÉ TATRY MTS., DOMIN 1943

121. Palenica Mt., $1140 \mathrm{~m}$ a.s.l.

122. Tatranská Kotlina

123. Drabina Mt., 760-820 m a.s.1.

124. Hučava, $970 \mathrm{~m}$ a.s.l.

125. Žihlavno, $980-990 \mathrm{~m}$ a.s.l.

126. Valley of Čierná Voda River

127. Valley of Milý Stream, $1160 \mathrm{~m}$ a.s.l.

128. Slope of Faixová Mt., $1070 \mathrm{~m}$ a.s.l.

129. Faixová Mt., 1500-1510 m a.s.l.

130. Valley of Holub, $1560-1650 \mathrm{~m}$ a.s.l.

131. Červená hlína, $1230-1380 \mathrm{~m}$ a.s.l.

132. Suchá Valley, $950-960 \mathrm{~m}$ a.s.1.

133. Dlúhý Vrch Mt., $800-1250 \mathrm{~m}$ a.s.l.

134. Valley of Babilovski stream, $790 \mathrm{~m}$ a.s.1.

135. Holý Vrch Mt. (under Bujači Mt.), 1230 m a.s.l.

136. Malý Podkosár, $1180 \mathrm{~m}$ a.s.l.

137. Velký Podkošár, 1340-1360 m a.s.l.

138. Javorinka, $1100-1200 \mathrm{~m}$ a.s.1.

139. Under Laštovica, $1340 \mathrm{~m}$ a.s.l.

140. Valley of Reglanski Stream, $1240 \mathrm{~m}$ and 1280-1300 m a.s.l.

141. Glosná skála, about $1420 \mathrm{~m}$ a.s.l.

142. Tristarská Valley, $1140 \mathrm{~m}$ and 1300-1360 m a.s.l.

143. Podspady, $920 \mathrm{~m}$ a.s.l.

144. Javorina, $1020 \mathrm{~m}$ a.s.l.

145. Kičura, Pieniny Mts., Domin 1943

146. Krutówka, Bieszczady Mts., $680 \mathrm{~m}$ a.s.l., Jasiewicz 1965

147. Between Ustrzyki Górne and Bereżki, Bieszczady Mts., $620 \mathrm{~m}$ a.s.l., Jasiewicz 1965

148. Caryńska mountain pasture, Bieszczady Mts., $1030 \mathrm{~m}$ a.s.l., Jasiewicz 1965

149. Valley of Chyornaya Tisa River, Svidovec Mts., Domin 1943, Malinovsky 1962

150. Valley of Wielikij Trostyanec River, Svidovec Mts., Domin 1943, Malinovsky 1962 


\section{Skurtul, Svidovec Mts., Domin 1943, Malinovsky 1962}

152. Valley of Lazestina Stream, Svidovec Mts., $750 \mathrm{~m}$ a.s.l., Domin 1943

153. Tatulska, Svidovec Mts., 1650-1750 m a.s.l., Domin 1943

\section{REFERENCES}

Białecka K., 1982. Rośliny naczyniowe grupy Pilska w Beskidzie Żywieckim. Zesz. Nauk. UJ, Pr. Bot. 10: 1-149.

Domin K., 1923. Problémy a metody Rostlinné Sociologie a jejich použiti pro výzkum lučnich a pastvinných porostú Republiky Československé. Praha. Ministerstvo Zemedelstvi Republiky Československé.

Domin K., 1929. Schedae ad floram Cechoslovenicam exsiccatam. Acta Bot. Bohem.: 44-79. Domin K., 1943. Monografická studie o rodu Dactylis L. Acta Bot. Bohem. 14: 3-147.

Domin K., Podpera J., 1928. Klic k uplné kvétené Republiky Československé. R. Promberger, Olomouc.

Flora Europaea. V., 1980. Tutin T. G. (ed.), Cambridge University Press, Cambridge-London. Hendrych R., 1986. Polozapomenuté a nové nálezy z květeny ČSR. Zpr. Čs. Bot. Společ. Praha 21: $45-55$.

Index Herbariorum. 1981. Holmgren P. K., Keuken W., Schofield E. K., Regnum Veg. 106 Jasiewicz A., 1965. Rośliny naczyniowe Bieszczadów Zachodnich. Mon. Bot. 20: 1-340.

Kondracki J., 1978. Geografia fizyczna Polski. Wyd. 3. PWN, Warszawa.

Lipa O. L., Fedoren ko A. P., 1969. Zapovedniki i pamyatniki prirody Ukrainy. Urozhay, Kiev. Lazar J., 1957. Gleby. Żywiecczyzny. Roczn. Nauk Roln. 76, A, 1: 65-105.

Lazar J., 1966. Gleboznawstwo z podstawowymi wiadomościami z geologii, mineralogii, petrografii i hydrogeologii. III, IV, PWN, Warszawa-Poznań.

Malinovsky K. A., 1962. Zabuti widy flori Ukrains'kich Karpat. Ukr. Bot. Zhurn. 19: 74-78. Mirek Z., (manuscr.) Polish Herbaria.

Mizianty M., 1988, Biosystematic studies on Dactylis L. 2. Original research. 2.1. Morphological differentiation and occurrence of representatives of the genus Dactylis in Poland. 2.1.1. Field studies and experimental cultures. Acta Soc. Bot. Pol. 57: 589-621.

Szafer W., Zarzycki K. (eds.), 1977. Szata roślinna Polski. II, PWN. Warszawa.

Szafran B., 1933. Badania nad trawami pastewnymi Karpat Wschodnich. 1. Kupkówka Aschersona (Dactylis Aschersoniana Graebn.) Pam. Państw. Inst. Nauk. Gosp. Wiejskiego w Puławach 14: 253-268.

Walas J., 1938. Wędrówki roślin górskich wzdłuż rzek tatrzańskich. Spraw. Kom. Fizjograf. PAU. 72: 1-131.

Zapałowicz H., 1889. Roślinna szata gór Pokucko-Marmaroskich. Spraw. Kom. Fizjograf. PAU. 24: 1-389.

Biosystematyczne studia Dactylis L. 2. Badania wlasne. 2.1. Zróżnicowanie morfologiczne $i$ występowanie przedstawicieli rodzaju Dactylis w Polsce. 2.1.2. Rozmieszczenie Dactylis glomerata subsp. slovenica (Dom.) Dom. w Polsce $i$ na terenach przyleglych

\section{Streszczenie}

W niniejszej pracy autorka prezentuje wyniki analizy materiałów zielnikowych z Polski, Czechosłowacji, NRD, ZSRR i swoich własnych, oraz danych z literatury na temat rozmieszczenia D.g. subsp. slovenica (Dom.) Dom. w Polsce i na terenach przyległych. Stwierdzono występowanie 
tego podgatunku na 33 stanowiskach (30 zielnikowych i 3 z literatury) w Polsce (rys. 1). Rozmieszczenie tego podgatunku jest prezentowane po raz pierwszy dla Polski. Wszystkie stanowiska są zlokalizowane w górzystej części Polski. Zgodnie z fizycznogeograficznym podziałem Polski, podgatunek ten występuje zarówno w Karpatach Zachodnich (Beskid Śląski, Kotlina Żywiecka, Beskid Makowski, Beskid Żywiecki, Beskid Sądecki, Pogórze Rożnowskie, Tatry, Pieniny), jak i w Karpatach Wschodnich (Góry Sanocko-Turczańskie, Zachodnie Bieszczady), jak również w Sudetach, które przynależą do Masywu Czeskiego. W liście stanowisk, w nawiasach podano odpowiednie nazwy jednostek geobotanicznego podziału Polski. Na obszarach przyległych do Polski, D.g. subsp. slovenica została znaleziona na licznych stanowiskach w Masywie Czeskim (Karkonosze, Jesionki, Kotlina Czeska), jak również stwierdzono liczne jej występowanie w Karpatach zarówno Zachodnich (Tatry, Pieniny, Fatra i inne), jak i Wschodnich (Skoliewskie Beskidy, Gorgany, Czarnohora i inne) oraz na Roztoczu. Znaleziono również 3 stanowiska poza Masywem Czeskim, Karpatami i Roztoczem. Są to 2 stanowiska na terenie ZSRR (Wyżyna Naddnieprzańska i Polesie Kijowskie) oraz 1 stanowisko na terenie Jugosławii (Góry Dynarskie). Fakt ten sugeruje, że występowanie tego podgatunku może dotyczyć nie tylko Masywu Czeskiego, Karpat Zachodnich i Wschodnich oraz Roztocza. Być może, że takson ten ma szerszy zasięg i występuje również w Karpatach Południowych i dalej w przyległych do nich Górach Dynarskich. Wszystkie znalezione w Polsce stanowiska D.g. subsp. slovenica są w zgodzie z wapieniolubnym charakterem tego podgatunku oraz potwierdzają to, że jest to roślina górska. Związana jest ona głównie $\mathrm{z}$ górskimi ziołoroślami, ale schodzi również niżej wzdłuż dolin potoków. 